\title{
PEMAANFAATAN LIMBAH LUMPUR PADAT DARI INDUSTRI PENYAMAKAN KULIT UNTUK PEMBUATAN BATA BETON PEJAL
}

\author{
(Utilization of Solid Sludge Waste from Tanning Industry for Production of \\ Solid Concrete Block)
}

Suliestiyah Wiryodiningrat ${ }^{1)}$

Email: suliestyah@yahoo.com

Diterima: 10 Agustus 2010

Disetujui: 13 Oktober 2010

\begin{abstract}
Solid sludge waste from the Tanning Industry is still a problem in exile, because it is considered as "B3" waste, and containing chromium. The objective of the research utilize solid sludge waste as a partial component of sand aggregate used in production of solid concrete block. This experiment was conducted with two types of variable i, e: 1). solid concrete block with coral 2). Solid concrete block without coral. Each variable has three variations in the composition of cement, sand and mud, that were 1 part cement: 5 parts sand and mud. From the physical test results, showing solid concrete block with were composition of 1 part cement: 4 parts sand: 1 part sludge (without coral) has met the physical requirements of solid concrete block concrete block classification standards, according to SNI-03-0348-1989 quality level IV, which has a minimum compressive strength of $30.25 \mathrm{~kg} / \mathrm{cm}^{2}$ (standard $25 \mathrm{~kg} / \mathrm{cm}^{2}$ ) and a maximum water absorption of $13.99 \%$ (standard - \%). Solid concrete block can be used for buildings that do not bear the burden and protected from the weather. Having held the test of leachate from solid concrete block with TCLP method turned out to produce chromium content: $4.017 \mathrm{mg} / \mathrm{l}$ is still below the threshold $(5.00 \mathrm{mg} / \mathrm{l})$, which means that concrete can be used for use outdoors (exposed to rain), because it will not pollute the soil and groundwater and can be transported / brought out the leather tanning factory environment.
\end{abstract}

Keywords: solid waste sludge, tannery industry, solid concrete block

ABSTRAK

Sampai saat ini limbah padat lumpur dari Industri Penyamakan Kulit masih menjadi masalah dalam pembuangannya, karena dianggap sebagai limbah B3, dan mengandung bahan kimia krom. Penelitian ini memanfaatkan limbah padat lumpur sebagai agregat pengganti sebagian pasir yang biasa digunakan dalam pembuatan bata beton pejal. Percobaan dilakukan dengan dua variabel jenis bata beton yaitu bata beton pejal menggunakan koral dan tidak menggunakan koral. Masing-masing variabel, terdiri atas tiga variansi komposisi semen, pasir dan lumpur, yaitu 1 bagian semen dengan 5 bagian pasir dan lumpur. Hasil uji sifat fisik, menunjukkan bahwa bata beton pejal yang dibuat dengan komposisi 1 bagian semen : 4 bagian pasir : 1 bagian lumpur (tanpa koral) memenuhi syarat fisik bata beton pejal. Menurut SNI-03-0348-1989 tergolong kualitas tingkat mutu IV yaitu mempunyai kuat tekan minimum 30,25 $\mathrm{kg} / \mathrm{cm}^{2}$ (standar $25 \mathrm{~kg} / \mathrm{cm}^{2}$ ) dan penyerapan air maksimum 13,99\% (standar $0 \%$ ). Bata beton pejal dapat digunakan untuk bangunan yang tidak memikul beban dan terlindungi dari cuaca ( hujan dan panas ). Lindi bata beton pejal dengan metode Toxicology Characteristic Leaching Procedure (TCLP) ternyata memiliki kadar krom, 4,017 mg/l dan merupakan nilai di bawah ambang batas maksimum yaitu 5,00 mg/l. Hal ini berarti bahwa bata beton pejal tersebut dapat digunakan untuk pemakaian di luar ruangan (terkena air hujan).

Kata kunci: limbah lumpur padat, industri penyamakan kulit, bata beton pejal

\section{PENDAHULUAN}

Industri penyamakan kulit di Indonesia mampu menyumbang devisa cukup besar dari sektor industri non-migas. Di lain pihak industri penyamakan kulit menghasilkan limbah padat sebagai hasil samping dan memiliki potensi sumber pencemaran lingkungan tanpa pengelolaan yang baik dan benar. Limbah padat dapat berupa bulu, sisa trimming, fleshing, shaving, buffing dan limbah padat dalam bentuk lumpur yang berasal dari unit pengolahan air limbah industri penyamakan kulit. Industri penyamakan kulit lazim dilengkapi unit pengolahan air limbah (UPAL) yang

\footnotetext{
1)Balai Besar Kulit, Karet dan Plastik, Yogyakarta
} 
menghasilkan lumpur. Menurut J. Raghava Rao dan T. Ramasani (2001), setiap 1 ton kulit sapi mentah yang diproses menjadi kulit jadi (finish leather), menghasilkan limbah lumpur padat kering, sebanyak $360 \mathrm{~kg}$. Hasil uji terhadap lumpur yang dihasikan UPAL industri penyamakan kulit di Perancis, yang dilakukan oleh (Valentin Post dkk, 2000) mengandung unsur bahan kimia antara lain : Chrom 8.000 - 20.000 (mg/kg), Cadmium 6 $(\mathrm{mg} / \mathrm{kg})$, Aluminium $5-15.000(\mathrm{mg} / \mathrm{kg})$, Sodium $4000-11.000$ (mg/kg), Calsium $8000-100.000$ $(\mathrm{mg} / \mathrm{kg})$, Barium $360(\mathrm{mg} / \mathrm{kg})$, Cloride 1.000 $30.000(\mathrm{mg} / \mathrm{kg})$, Sulphur $500-2.000(\mathrm{mg} / \mathrm{kg})$ dan Carbon $22 \%$.

Menurut Thierry Poncet (1998), salah satu alternatif pengelolaan lumpur adalah pembuangan ke penampungan akhir "Landfill" (J. Ludvik, 2000) karena lumpur sebagai bahan berbahaya dan beracun (B3). Berdasarkan pemantauan yang dilakukan maka baik di dalam negeri maupun di luar negeri permasalahan pokok yang dihadapi industri penyamakan kulit adalah pengelolaan limbah lumpur. Permasalahan transportasi (handling) dan biaya yang relatif mahal serta tempat pembuangan / penampungan limbah yang memenuhi syarat dan memadai belum banyak tersedia. Sebagai contoh di negara Eropa Timur untuk membuang limbah padat lumpur biayanya mencapai US \$200/ton, sedangkan di Jepang biayanya sebesar US \$250/ton. Di Indonesia baru memiliki satu tempat pembuangan limbah B3 yang direkomendasikan oleh Pemerintah yaitu di Pusat Pembuangan Limbah Industri (PPLI) - Cileungsi, Bogor. Menurut hasil penelitian (Sri Sutiyasmi dkk, 2004) lumpur dari industri penyamakan kulit mengandung Calsium $(\mathrm{Ca}) 10-30 \%$, Nitrogen $(\mathrm{N})$ $2-10 \%$, Krom $(\mathrm{Cr}) 0,2-3 \%$, Besi (Fe) $0-12 \%$ dan Aluminium (Al) $0-6 \%$. Lumpur dari industri penyamakan kulit yang mengandung unsur aluminium dan besi dapat menggantikan semen yang biasa digunakan untuk bahan pembuatan bata beton. Semen mengandung silikat-silikat kalsium dan gips sebagai bahan pembantu. Oksida-oksida yang terdapat dalam semen adalah $\mathrm{Kapur}(\mathrm{CaO}) 60$ $-66 \%$, Silika (SiO) $16-25 \%$, Alumunium (Al2O3) $3-8 \%$, Besi (Fe2O3) $1-5 \%$ (A. H.Andriati, 2000).

Alternatif lain pengelolaan limbah padat lumpur adalah pemanfaatan limbah untuk pembuatan bata, bata beton, maupun paving block, brick (J. Raghava Rao dan T. Ramasani, 2001), (Dott Michele Tomaselli, 1999), (Sahasranaman. A., 1998) setelah dibuat bata beton lindi yang dihasilkan memenuhi syarat untuk aman dibuang, tanpa mengganggu lingkungan. Beton adalah bahan yang diperoleh dengan mencampurkan agregat halus, agregat kasar, air dan semen Portland atau bahan pengikat hidrolis yang sejenis dengan atau tanpa tambahan bahan yang lain. Campuran dari agregat halus, air dan semen disebut adukan atau Mortar (A. H. Adriati, 2000).

Bahan galian golongan $\mathrm{C}$ (pasir) penggunaannya mulai dibatasi, sehingga harga pasir menjadi mahal. Oleh karena itu perlu dicari bahan pengganti / substitusi sebagai pengganti pasir atau mencampur dengan bahan yang murah.

Menurut SNI 03-0348-1989, bata beton pejal adalah bata yang memiliki penampang pejal lebih besar $75 \%$ dari luas penampang seluruhnya dan memiliki volume pejal lebih dari $75 \%$ dari volume bata seluruhnya.

Penelitian tentang pembuatan bata beton pejal dengan pemanfaatan limbah "sludge" dari kertas sigaret sebagai pengganti agregat pasir telah dilakukan oleh Henggar Hardiani dan Susi Sugesty (2009). Bata beton pejal yang dihasilkan memiliki kualitas II dan III (SNI 03-0348-1989).

Penelitian tentang pemanfaatan limbah padat lumpur (dried sludge) dari industri penyamakan kulit untuk pembuatan bata beton pejal bertujuan untuk mengurangi pencemaran lingkungan. Bata beton pejal dapat dimanfaatkan untuk bahan bangunan yang lebih murah.

\section{BAHAN DAN METODE \\ Bahan Penelitian}

Bahan penelitian terdiri atas semen, pasir, lumpur padat, koral dan air. Spesifikasi bahan penelitian adalah sebagai berikut :

Lumpur padat dipakai untuk pembuatan bata beton pejal berupa lumpur liat diperoleh dari UPAL industri penyamakan kulit di Yogyakarta, pasir sebagai agregat halus adalah pasir sungai yang diperoleh dari penjual bahan bangunan, semen yang digunakan adalah semen Portland yang diperoleh dari toko besi, koral ukuran sebesar kelereng diambil dari sungai sebagai bahan pengisi, agar kebutuhan pasir dapat dikurang $j$ atau menambah kekuatan, air sumur sebagai unsur penting dalam pembuatan bata beton pejal.

\section{Alat Penelitian}

Alat pencetak bata beton pejal memiliki ukuran panjang $400 \mathrm{~mm}$, lebar $200 \mathrm{~mm}$, dan tebal $100 \mathrm{~mm}$. Ayakan agregat dengan ukuran lubang 4,8 mm, sekop, alat pencampur (mollen), 
timbangan dan ember plastik.

Metode

Raucangan Percobaan

Rancangan percobaan mengikuti ketentuan Persyaratan Umum Bahan Bangunan di Indonesia (PUBI-1982) dengan formula 1 bagian semen dan
5 bagian agregat pasir. Formula tersebut lazim dilakukan oleh UKM, dan untuk mengurangi jumlah pasir dapat ditambah koral. Limbah padat lumpur sebagai pengganti sebagian agregat pasir ditambahkan menurut variasi jumlah seperti disajikan pada Tabel 1.

Tabel 1 : Rancangan penelitian pembuatan bata beton pejal

\begin{tabular}{|c|c|c|c|}
\hline \multirow{2}{*}{ Bahan Pengganti Pasir } & \multicolumn{3}{|c|}{ Bahan Utama (bagian) } \\
\cline { 2 - 4 } & Semen & Pasir & Lumpur Padat \\
\hline \multirow{3}{*}{$\begin{array}{c}\text { Tanpa Koral } \\
\text { (A) }\end{array}$} & $1(\mathrm{a})$ & $4(\mathrm{a})$ & $1(\mathrm{a})$ \\
\cline { 2 - 4 } & $1(\mathrm{~b})$ & $3(\mathrm{~b})$ & $2(\mathrm{~b})$ \\
\cline { 2 - 4 } & $1(\mathrm{c})$ & $2(\mathrm{c})$ & $3(\mathrm{c})$ \\
\hline \multirow{3}{*}{$\begin{array}{c}\text { Dengan Koral } 10 \% \\
\text { ( B ) }\end{array}$} & $1(\mathrm{~d})$ & $1(\mathrm{~d})$ & $4(\mathrm{~d})$ \\
\cline { 2 - 4 } & $1(\mathrm{a})$ & $4(\mathrm{a})$ & $1(\mathrm{a})$ \\
\cline { 2 - 4 } & $1(\mathrm{~b})$ & $3(\mathrm{~b})$ & $2(\mathrm{~b})$ \\
\cline { 2 - 4 } & $1(\mathrm{c})$ & $2(\mathrm{c})$ & $3(\mathrm{c})$ \\
\hline
\end{tabular}

\section{Pembuatan Bata Beton Pejal}

Bahan-bahan dicampur dengan perbandingan tertentu sesuai dengan pelaksanaan yang biasa dilakukan di lapangan dan dicetak secara manual (Tabel 1).

Lumpur liat dibuat adonan terlebih dahulu dengan cara diaduk dan ditambah air agar mudah dicampur dengan semen dan pasir. Pasir diayak agar pecahan-pecahan batu atau kerikil dapat dipisahkan. Koral dipilih dengan ukuran seragam sebesar kelereng. Masing-masing bahan ditimbang sesuai formula (Tabel 1).

\section{Pencampuran bahan}

Agregat dicampur dengan semen kemudian diaduk sampai rata, selanjutnya ditambah air secukupnya dan jumlah air dihitung berdasarkan berat semen dan agregat. Adonan hasil pengadukan siap dicetak.

\section{Pencetakan}

Pencetakan dilakukan penekanan dengan alat penekan dari besi agar padat dan memenuhi seluruh cetakan. Dibuat 2 jenis bata beton pejal, pertama jenis bata beton pejal tanpa koral dan kedua jenis bata beton pejal ditambah koral sebanyak $10 \%$ dari jumlah pasir digunakan sekaligus sebagai pengganti pasir. Setelah cetakan penuh dan kelihatan padat kemudian cetakan dibalik dan dibuka untuk mengeluarkan bata beton pejal. Bata beton pejal diberi kode dan nomor urut sesuai dengan formula yang dirancang (Tabel 1).

\section{Pemeliharaan/curing}

Bata beton pejal basah dijemur selama 24 jam, dan disimpan di tempat teduh. Setelah penyimpanan 28 hari, bata beton pejal siap dipakai atau dipasarkan. Penyimpanan lebih dari 45 hari bata beton pejal menjadi kering dan perlu disemprot air 2 hari sekali.

Pengujian limbah lumpur padat dan beton, serta lindi beton hasil percobaan

Pengujian limbah padat lumpur dilakukan di Laboratorium Pengujian Limbah dan Lingkungan dan Aneka Komoditi, Balai Riset dan Standardisasi Industri dan Perdagangan, Semarang. Dalam pengujian limbah lumpur padat menggunakan metode uji AAS. Pengujian fisik bata beton pejal dilakukan di Laboratorium Bahan Bangunan Fakultas Teknik Jurusan Teknik Sipil, Universitas Gadjah Mada, Yogyakarta. Standar yang digunakan untuk penilaian hasil adalah SNI03-0348-1989 untuk Persyaratan Fisik Batu Beton Pejal. Metode uji pelindian menguji bata beton pejal dengan metode Toxicology Characteristic Leaching Procedure (TCLP). 


\section{Sifat Kuat Tekan}

Pengaruh jenis atau komponen penyusun bahan bata beton pejal terhadap sifat kuat tekan dapat dilihat pada Gambar 1 dan Gambar 2.

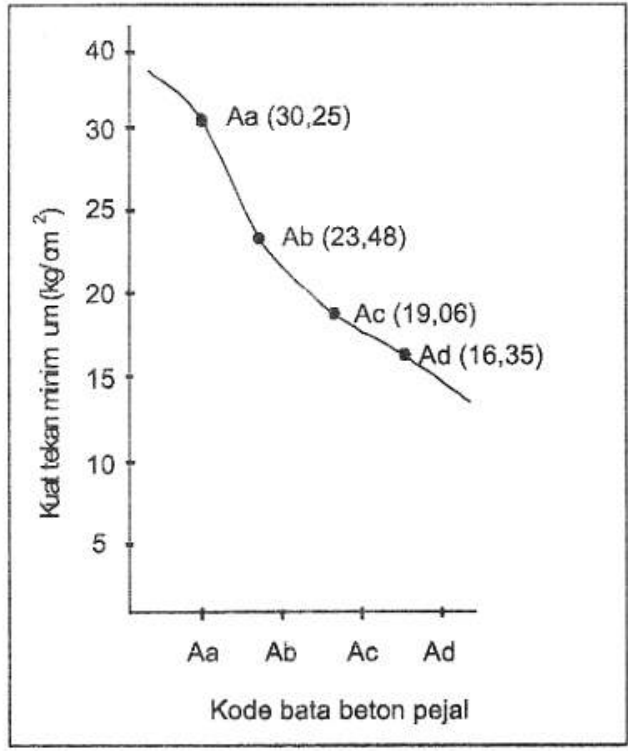

Gambar 1. Hasil uji sifat fisik bata beton pejal (tanpa koral) terhadap kuat tekan $\left(\mathrm{kg} / \mathrm{cm}^{2}\right)$

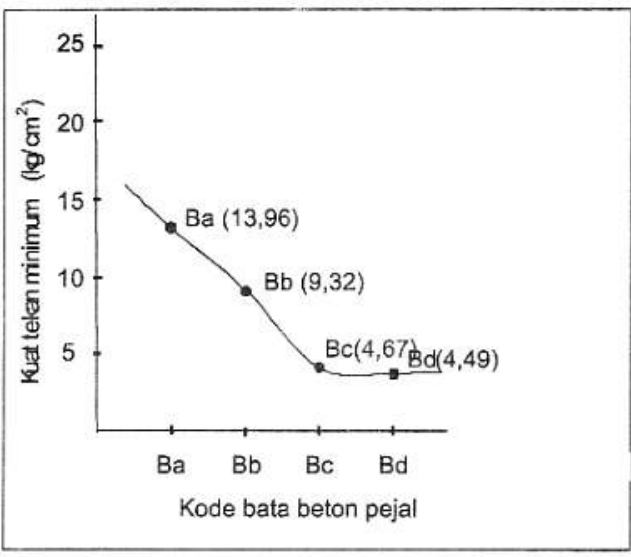

Gambar 2. Hasil uji sifat fisik bata beton pejal (dengan koral) terhadap kuat tekan $\left(\mathrm{kg} / \mathrm{cm}^{2}\right)$

Gambar 1 dan 2 menunjukkan bahwa makin banyak digunakan lumpur padat sebagai pengganti agregat pasir, maka kuat tekan bata beton pejal semakin turun. Hal ini sesuai dengan pendapat (Tjokrodimuljo, 1996) yang menyatakan bahwa lumpur pada agregat akan menghalangi lekatan pasta semen dan sangat berpengaruh terhadap nilai kuat tekan bata beton pejal yang dihasilkan.

Lumpur padat yang dihasilkan dari industri penyamakan kulit ternyata mengandung protein dan lemak serta garam sulfat yang cukup mengganggu pada kekuatan ikatan antara semen dengan agregat lain dan dampaknya adalah turunnya kekuatan tekan bata beton pejal. Hal ini sesuai dengan pendapat (Tjokrodimulyo dan Kardiono, 1996).

Air untuk mencampur semen dan agregat lain cukup banyak, karena lumpur padat yang digunakan sangat liat. Agar hasil adukan (adonan) rata diperlukan banyak air. Menurut Tjokrodimulya dan Kardiono (1996) penggunaan air pada pembuatan bata beton pejal yang melampaui jumlah $25 \%$ akan menimbulkan reaksi kimia yang membentuk pori-pori pada adonan. $\mathrm{Hal}$ ini berakibat mengurangi kekuatan bata beton pejal, karena bata beton pejal yang dihasilkan banyak berongga.

Sesuai dengan Persyaratan Klasifikasi Bata Beton Pejal menurut SNI-03-0348-1989, maka hanya bata beton pejal dengan kode Aa (tanpa koral, 1 bagian semen, 4 bagian pasir dan 1 bagian lumpur padat), memiliki kekuatan sebesar 30,35 $\mathrm{kg} / \mathrm{cm}^{2}$ memenuhi syarat kuat tekan minimum sebesar $25 \mathrm{~kg} / \mathrm{cm}^{2}$. Berdasarkan analisa statistik menggunakan analisis variansi Rancangan Acak Lengkap (Astuti, 1980) dengan tingkat signifikan $0,05 \%$, maka formulasi semen, lumpur, pasir dan air dengan komponen lumpur sampai 4 bagian, ternyata hasilnya tidak berbeda nyata $(p>0,05)$ terhadap kuat tekan bata beton pejal baik yang tidak menggunakan koral maupun menggunakan koral (Tabel 3). Jika hasil uji sifat fisik bata beton pejal tanpa koral dibandingkan bata beton pejal dengan ditambah koral terhadap kuat tekan disajikan pada Gambar 3 .

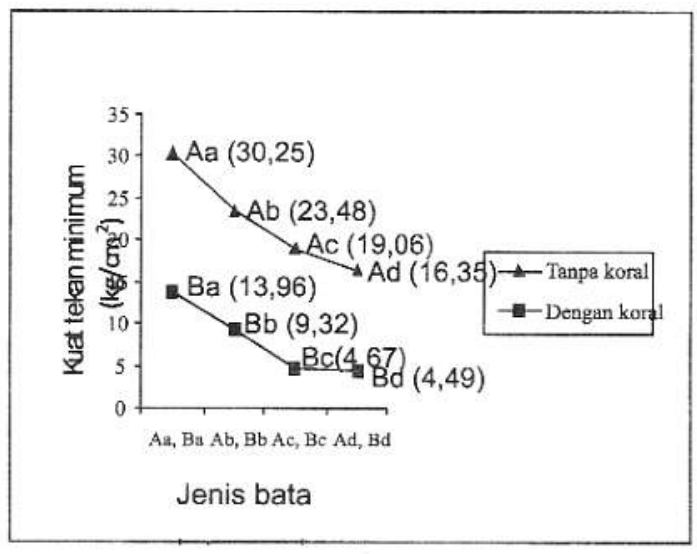

Gambar 3. Hasil uji kuat tekan minimum $\left(\mathrm{kg} / \mathrm{cm}^{2}\right)$ 


\section{Analisa Data}

Data pengujian yang diperoleh dianalisa secara statistik dengan menggunakan analisis Variansi Rancangan Acak Lengkap Pola Searah. Perbedaan. rerata perlakuan diuji dengan Duncan's New Multiple Range Test (Astuti, 1980).

\section{HASIL DAN PEMBAHASAN}

Masing-masing formula (8 formula) dibuat bata beton pejal sebanyak 15 buah. Dengan demikian dapat dihasilkan bata beton pejal sebanyak 120 buah dengan ukuran panjang \pm 399 $\mathrm{mm}$, tebal $\pm 99 \mathrm{~mm}$ dan lebar $\pm 165 \mathrm{~mm}$.

\section{Pengujian}

Pengujian dilekukan untuk 2 jenis limbah lumpur padat yaitu : limbah lumpur padat berwarna coklat dan limbah lumpur padat berwarna abu-abu kehitaman. Tujuan pengujian adalah untuk mengetahui kadar krom dalam limbah lumpur padat.

\section{Pengujian Lumpur}

Hasil limbah lumpur padat seperti disajikan pada Tabel 2.

Tabel 2 : Hasil limbah lumpur padat

\begin{tabular}{|c|c|c|c|c|}
\hline Warna Lumpur & Kode contoh & Parameter & Satuan & Hasil uji \\
\hline Abu-abu kehitaman & PBPD.17 & $\mathrm{C}_{\mathrm{r}}$ total & $\mathrm{ppm}$ & $7.141,40$ \\
\hline Merah kecoklatan & PBPD.16 & $\mathrm{C}_{\mathrm{r}}$ total & $\mathrm{ppm}$ & $6.003,31$ \\
\hline
\end{tabular}

Hasil uji limbah lumpur padat basah (Tabel 2) menunjukkan bahwa limbah lumpur padat masih mengandung krom cukup tinggi dan di atas ambang batas yang disyaratkan. Lumpur padat berwarna abu-abu kehitaman yang berasal dari proses penyamakan full chrome lebih tinggi dibanding kandungan lumpur berwarna merah kecoklatan yaitu dari proses penyamakan kombinasi dengan nabati. Hal ini sesuai dengan pendapat (Valentine. Post dkk, 1999) bahwa limbah dari proses penyamakan kulit menggunakan bahan penyamak full krom menghasilkan limbah dengan kandungan krom lebih tinggi dibandingkan dengan proses penyamakan menggunakan bahan penyamak kombinasi (krom dengan nabati). Limbah lumpur padat sebelum dibuang harus diolah terlebih dahulu agar kadar kromnya memenuhi ambang batas sesuai dengan ketentuan pemerintah.

Pengujian Sifat Fisika Bata Beton Pejal

Kualitas bata beton pejal dipengaruhi oleh jenis bahan untuk pembuatan bata beton pejal, yaitu komponen semen dengan agregat pasir dan lumpur dan jumlah air yang digunakan. Kekuatan tekan bata beton pejal sangat dipengaruhi oleh tingkat penyerapan air. Adapun hasil uji fisik bata beton pejal disajikan pada Tabel 3 .

Tabel 3 : Hasil uji fisik bata beton pejal terhadap parameter kunci

\begin{tabular}{|c|c|c|c|c|c|}
\hline $\begin{array}{c}\text { Bahan Pengganti } \\
\text { Pasir }\end{array}$ & Kode & $\begin{array}{c}\text { Umur } \\
\text { (hari) }\end{array}$ & $\begin{array}{c}\text { Berat Jenis } \\
\left(\mathbf{g r a m} / \mathbf{c m}^{3}\right)\end{array}$ & $\begin{array}{c}\text { Kuat Tekan } \\
\text { Minimum } \\
\left(\mathbf{k g}^{2} \mathbf{c m}\right)\end{array}$ & $\begin{array}{c}\text { Serapan maks. } \\
\text { air (\% berat) }\end{array}$ \\
\hline \multirow{4}{*}{ Tanpa Koral } & $\mathrm{Aa}$ & 45 & 1829 & 30,25 & 13,99 \\
\cline { 2 - 6 } & $\mathrm{Ab}$ & 45 & 1715 & 23,48 & 17,96 \\
\cline { 2 - 6 } & $\mathrm{Ac}$ & 45 & 1778 & 19,06 & 22,16 \\
\cline { 2 - 6 } & $\mathrm{Ad}$ & 45 & 1765 & 16,35 & 25,76 \\
\hline & $\mathrm{Ba}$ & 45 & 1712 & 13,96 & 19,89 \\
\hline \multirow{4}{*}{ Dengan Koral 10\% } & $\mathrm{Bb}$ & 45 & 1756 & 9,32 & 25,05 \\
\cline { 2 - 6 } & $\mathrm{Bc}$ & 45 & 1508 & 4,67 & 27,60 \\
\cline { 2 - 6 } & $\mathrm{Bd}$ & 45 & 1432 & 4,49 & 35,01 \\
\hline
\end{tabular}


Gambar 3 menunjukkan bahwa rata-rata hasil uji sifat fisik jenis bata beton pejal yang dibuat tanpa koral dan ditambah koral 10\% dari jumlah pasir terjadi penurunan yaitu makin banyak menggunakan lumpur padat sebagai pengganti pasir, maka kuat tekan bata beton pejal akan makin turun. Hasil uji menunjukkan bahwa bata beton pejal tanpa koral dengan kode berturut-turut : $\mathrm{Aa}$; $\mathrm{Ab}$; Ac dan Ad memberikan kuat tekan minimum sebesar berturut-turut : 30,$25 ; 23,48 ; 19,06$ dan $16,35 \mathrm{~kg} / \mathrm{cm}^{2}$. Sedangkan bata beton pejal menggunakan koral dengan kode berturut-turut : $\mathrm{Ba} ; \mathrm{Bb} ; \mathrm{Bc}$ dan $\mathrm{Bd}$, memberikan kuat tekan minimum sebesar berturut-turut: 13,$96 ; 9,32 ; 4,67$ dan $4,49 \mathrm{~kg} / \mathrm{cm}^{2}$. Berdasar standar SNI-03-03481989, maka hasil uji kuat tekan menunjukkan bahwa bata beton pejal dengan kode Aa memenuhi syarat deugan knal tekan di atas syarat yang ditentukan sabesar minimum $2.5 \mathrm{~kg} / \mathrm{cm}^{2}$. Sedangkan bata beton pejal merggunakan koral, memiliki kuat tekan di bawah persyaratan yang ditentukan oleh 5NT-03-0348-1989. Menurut Tjokrodimuljo (1996), bahwa lumpur pada agregat dapat menghalangi lekatan pasta semen, dan besar pengaruhnya terhadap nilai kuat tekan. Kuat tekan bata beton pejal dipengaruhi oleh kepadatan, jenis semen, jenis agregat, berat jenis adonan serta umur bata beton pejal. Penurunan kuat tekan bata beton pejal hasil percobaan dapat disebabkan oleh limbah lumpur padat yang ditambahkan termasuk agregat ringan dengan volume pori tertutup. Oleh sebab itu memiliki kuat hancur kurang baik ditunjang dengan penekanan agregat maka bata beton pejal mudah hancur.

Air dan agregat untuk pembuatan bata beton pejal harus bersih dari zat organik, garam sulfat, lumpur, lemak, protein dan lain-lain. Dalam penelitian ini digunakan lumpur padat dari industri penyamakan kulit sebagai pengganti sebagian agregat pasir. Padahal lumpur padat dari industri penyamakan kulit banyak mengandung protein dan lemak serta garam sulfat yang akan mengganggu kekuatan ikatan semen dengan agregat lain menyebabkan turunnya kekuatan tekan bata beton pejal tersebut. Hal ini sesuai dengan pendapat (Tjokrodimuljo, 1996).

Penambahan koral akan membentuk banyak pori-pori dalam bata beton pejal, dan berdampak pada tingginya penyerapan air, maka mutu bata beton pejal yang dibasilkan relatif rendah. Temuan ini sesuai dengan hasil penelitian yang dilakukan oleh (L. J. Murdock dan K. M. Brook, 1981). Untuk mencapai adonan homogen dalarn pembuatan bata beton pejal biasanya digunakan air sebanyak $25 \%$ dari jumlah semen dan agregat penyusun bata beton pejal. Dalam penelitian ini digunakan air sekitar $25-40 \%$, karena lumpur padat yang digunakan sebagai pengganti sebagian agregat pasir bentuknya padat, liat dan basah. Oleh sebab itu homogenitas campuran tersebut diperlukan cukup banyak air, maka bata beton pejal yang dihasilkan banyak berpori-pori akibatnya bata beton pejai mudah rapuh dan lunak.

Berdasarkan analisa statistik menggunakan analisis variansi Rancangan Acak Lengkap (Astuti, 1980) terhadap hasil uji kuat tekan dengan tingkat signifikan $0,05 \%$, maka penggunaan formula semen, lumpur, pasir dan air, dengan komponen lumpur sampai 4 bagian, ternyata hasilnya tidak berbeda nyata $(p>0,05)$ terhadap kuat tekan bata beton pejal baik yang ditambah koral maupun tanpa koral. Sedangkan hasil kuat tekan bata beton pejal yang tidak menggunakan koral dan menggunakan koral apabila dibandingkan, maka hasilnya berbeda nyata $(\mathrm{p}<$ 0,05 ), kecuali pada kode bata beton pejal $\mathrm{Ba}$, yaitu bata beton pejal menggunakan koral, dengan perbandingan formulasi : 1 bagian semen, 4 bagian pasir, 1 bagian lumpur dan menggunakan air sebanyak $25 \%$.

\section{Sifat Serapan Ain $(\%)$}

Kualitas bata beton pejal juga sangat dipengaruhi oleh hasil uji bata beton pejal terhadap serapan air. Makin kecil sifat serapan air yang dimiliki, maka bata beton pejal tersebut makin kuat (PUBI-1982).

Adapun hasil uji sifat fisik serapan air untuk bata beton pejal tanpa koral, seperti disajikan pada Gambar 4 dan 5 .

Gambar 4 dan 5 menunjukkan bahwa makin banyak lumpur sebagai pengganti agregat pasir yang ditambabkan, maka bata beton pejal semakin tinggi serapan airnya, baik jenis bata beton pejal tanpa koral, maupun ditambah koral. Hasil uji serapan air bata beton pejal jenis sampel : $\mathrm{Aa} ; \mathrm{Ab}$; Ac dan Ad berturut-turut : 13,$99 ; 17,96 ; 22,16$ dan $25,76 \%$. Sedangkan bata beton pejal tambah koral untuk jenis sampel : $\mathrm{Ba} ; \mathrm{Bb} ; \mathrm{Bc}$ dan $\mathrm{Bd}$, berturutturut sebesar : 19,$89 ; 25,05 ; 27,60$ dan $35,01 \%$. Jika dibandingkan dengan persyaratan SNI-030348-1982, maka hanya bata beton pejal untuk sampel Bd yang tidak memenuhi syarat karena mempunyai sifat serapan air melebihi ketentuan yang disyaratkan yaitu maksimum sebesar $35 \%$, sedangkan bata beton pejal kode $\mathrm{Bd}$, mempunyai 
serap air sedikit di atasnya yaitu $35,01 \%$.

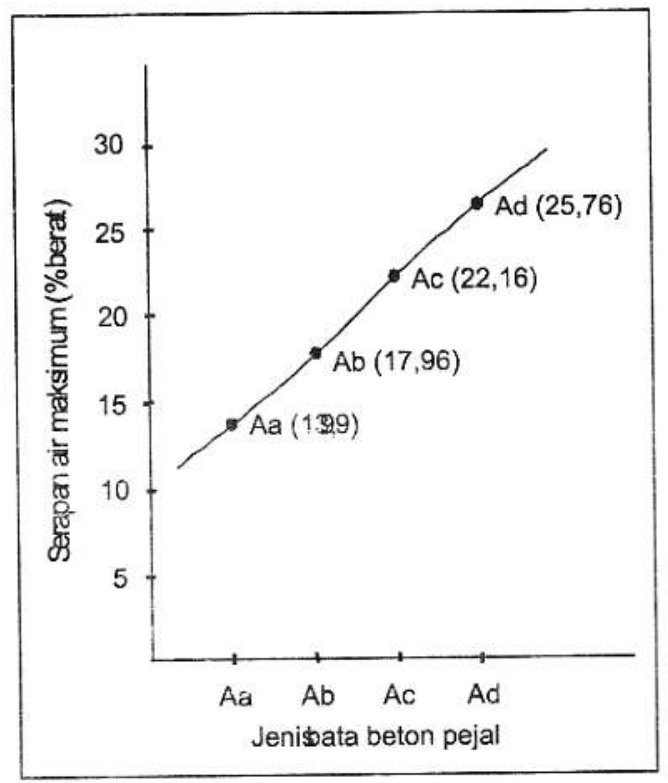

Gambar 4. Hasil uji sifat fisik bata beton pejal (tanpa koral) terhadap serapan air

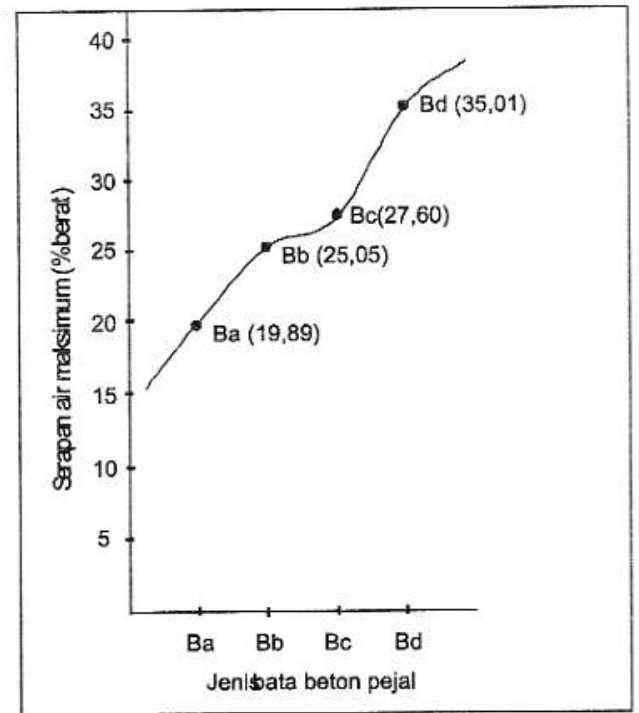

Gambar 5. Hasil uji sifat fisik bata beton pejal (dengan koral) terhadap serapan air

Gambar 4 dan 5 menunjukkan bahwa makin banyak lumpur sebagai pengganti agregat pasir yang ditambahkan, maka bata beton pejal semakin tinggi serapan airnya, baik jenis bata beton pejal tanpa koral, maupun ditambah koral. Hasil uji serapan air bata beton pejal jenis sampel : $\mathrm{Aa} ; \mathrm{Ab}$; Ac dan Ad berturut-turut : 13,$99 ; 17,96 ; 22,16$ dan
$25,76 \%$. Sedangkan bata beton pejal tambah koral untuk jenis sampel : $\mathrm{Ba}$; $\mathrm{Bb} ; \mathrm{Bc}$ dan $\mathrm{Bd}$, berturutturut sebesar : 19,$89 ; 25,05 ; 27,60$ dan $35,01 \%$. Jika dibandingkan dengan persyaratan SNI-030348-1982, maka hanya bata beton pejal untuk sampel Bd yang tidak memenuhi syarat karena mempunyai sifat serapan air melebihi ketentuan yang disyaratkan yaitu maksimum sebesar $35 \%$, sedangkan bata beton pejal kode Bd, mempunyai serap air sedikit di atasnya yaitu $35,01 \%$.

Penambahan koral ternyata menimbulkan banyaknya pori-pori bagian dalam bata beton pejal, yang berdampak tingginya serapan air sehingga mutu bata beton pejal tersebut turun. Temuan ini sesuai dengan hasil penelitian L. J. Murdock dan K. M. Brook (1981). Untuk mendapatkan adonan homogen pada pembuatan bata beton pejal biasanya digunakan air sebanyak $25 \%$ dari jumlah semen dan agregat komponen lain penyusunnya. Percobaan ini digunakan air antara $25-40 \%$ karena lumpur sebagai pengganti sebagian agregat pasir dalam keadaan padat dan liat.

Berdasarkan analisa statistik dengan tingkat signifikan $0,05 \%$, maka penggunaan formula semen, lumpur, pasir dan air, dengan komponen lumpur sampai 4 bagian, ternyata hasilnya tidak berbeda nyata $(p \geq 0,05)$ terhadap serapan air dari bata beton pejal baik tanpa koral, maupun ditambah koral.

Pengaruh jenis bata beton pejal dan komponen bahan terhadap sifat serapan air bata beton pejal tanpa koral dan ditambahkan koral seperti disajikan pada Gambar 6 .

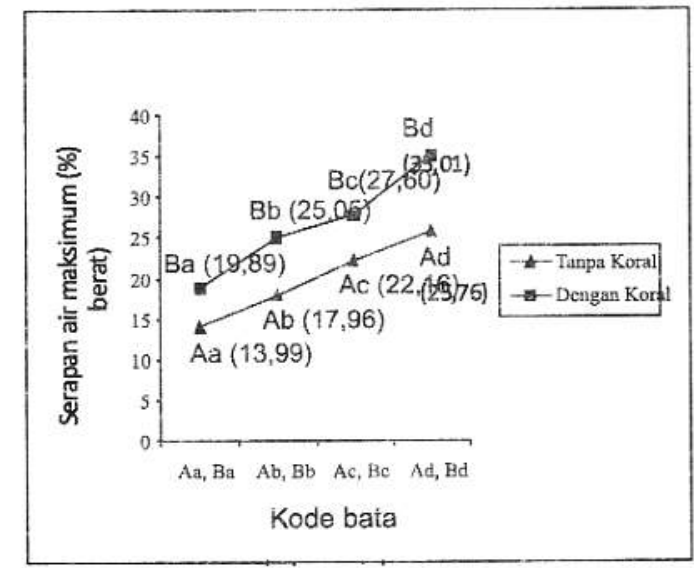

Gambar 6. Hasil uji serapan air maksimum (\%)

Gambar 6 menunjukkan bahwa serapan air 
bata beton tanpa koral dan ditambah koral makin tinggi dengan banyaknya agregat lumpur yang ditambahkan sebagai pengganti jumlah pasir.

\section{Pengujian Leached / Lindi Bata Beton Pejal}

Guna memenuhi keputusan Kepala Bapedal

No : Kep.04/BAPEDAL/09/1995, maka bata beton pejal perlu uji terhadap sifat fisik seperti lindi untuk mengetahui apakah bata beton pejal yang dihasilkan masih mengandung limbah B3 di atas ambang batas.

Hasil uji sampel bata beton pejal menunjukkan kadar krom sebesar : 4,017 mg/l, yang masih berada di bawah ambang batas (maksimum 5,00 mg/1). Hal ini berarti bata beton pejal dapat dipakai di luar ruangan (terkena air hujan).

Berdasarkan Klasifikasi Bata Beton Pejal menurut SNI-03-0348-1989, maka dari hasil uji bata beton pejal yang dibuat dengan memiliki karakteristik sebagai berikut:

1. Bata beton pejal jenis sampel Aa mempunyai klasifikasi atau golongan IV. Bata beton pejal ditandai oleh kuat tekan minimum sebesar $30,25 \mathrm{~kg} / \mathrm{cm}^{2}$ (standard minimum $25 \mathrm{~kg} / \mathrm{cm}^{2}$ ) dan penyerapan air maksimum sebesar 13,99\% (meskipun tidak disyaratkan).

Bata beton pejal dapat digunakan untuk dinding nonstruktural (tidak memikul beban) dan terlindungi dari cuaca (panas dan dingin).

2. Bata beton jenis sampel Ab, Ac dan Ad mempunyai kuat tekan minimum di bawah standar yang ditetapkan dalam SNI-03-03481989, oleh sebab itu beton pejal ini tidak dapat digunakan sebagai bahan bangunan.

3. Bata beton pejal dengan jenis sampel $\mathrm{Ba}, \mathrm{Bb}$, $\mathrm{Bc}$ dan $\mathrm{Bd}$, berdasarkan kuat tekan minimum, maka semua tidak memenuhi persyaratan dalam SNI-03-0348-1989.

\section{KESIMPULAN}

(1) Hasil uji lumpur padat industri penyamakan kulit masih mengandung kadar krom sangat tinggi dan melebihi ambang batas yang ditentukan. Setelah dimanfaatkan menjadi bata beton pejal, kadar kromnya berada di bawah ambang batas yang dipersyaratkan.

(2) Hasil uji lindi kadar krom bata beton pejal sebesar $4,017 \mathrm{mg} / 1$ di bawah ambang batas yang ditentukan maksimum $5,00 \mathrm{mg} / 1$.

(3) Lumpur yang dihasilkan sebagai limbah padat dari industri penyamakan kulit dapat dimanfaatkan menjadi bata beton pejal sebagai pengganti agregat pasir maksimum sebesar $3 / 5$ bagian dari jumlah pasir yang digunakan.

(4) Pemanfaatan lumpur padat limbah industri penyamakan kulit sebagai bahan pengganti agregat pasir untuk pembuatan bata beton pejal ternyata formula dengan komponen 1 bagian semen, 4 bagian pasir, dan 1 bagian lumpur ( $\mathrm{Aa}$ ) memenuhi standar bata beton pejal mutu IV yaitu dengan kuat tekan 30,25 $\mathrm{kg} / \mathrm{cm}^{2}$ dan serapan air $13,99 \%$. Bata beton pejal jenis ini dapat untuk dinding non strukural yang terlindung dari cuaca (panas dan dingin).

\section{DAFTAR PUSTAKA}

Adiet, J., 1999. Utilization of Tannery by Products.AILCA, Iqualda, Spain. World Leather.

Andriati, A.H., 2000. Pengaruh Penambahan Bahan Tambahan Jenis D pada Beton. Jurnal Permukiman. Pusat Penelitian dan Pengembangan Permukiman Departemen Pekerjaan Umum.

Anonim, 1982. Persyaratan Umum Bahan Bangunan di Indonesia (PUBI-1982). Pusat Penelitian dan Pengembangan Pemukiman, Bandung. Hal 29.

Anonim, 2003. Pemanfaatan Agregat Halus (Pasir) untuk Komponen Bangunan. Makalah. Departemen Kimpraswil, Balitbang Puslitbang Permukiman

ASTM D. 3666-01-2003. Standard Specification or Minimum Requirements for Agencies Testing and Inspecting Road and PavingMaterials. Pg: 369-374.

Astuti, M., 1980. Rancangan Percobaan dan Analisa Statistik. Fakultas Peternakan. Universitas Gadjah Mada, Yogyakarta.

Dott Michele Tomaselli, 1999. Treating Sludges and Solid residues. Stazione Sperimentale per I'Industria delle Pelli e delle Matere Concianti, Ital World Leather, November 1999, volume 12, number 7 ,page 26

Henggar Hardiani dan Susi Sugesti, 2009. Pemanfaatan Limbah Sludge Industri Kertas Sigaret untuk Bahan Baku Bata Beton. Berita Selullose, Vol. 44, No. 2.

Ludvik, J., 2000.Chrome Management In The Tanyard. Regional Programme for Pollution Control in The Tanning Industry In Souh-East Asia. 
Made Anom Wiryasa Ngk dan I Wayan Sudarsana, 2009. Pemanfaatan Lumpur Lapindo Sebagai Bahan Substitusi Semen dalam Pembuatan Bata Beton Pejal. Jurnal Ilmiah Teknik Sipil Vol 13, No. 1.

Mefri Dian Rosyida, 2007. Pengaruh Penambahan Tras Mulia pada Beton Berlubang Ditinjau Terhadap Kuat Tekan dan Serapan Air. Universitas Negeri Semarang.

Murdock, L.J. \& Brook, K.M.,1981. Bahan dan Praktek Beton. Penerbit Erlangga, Jakarta.

Mustain, 2006. Uji Kuat Tekan dan Serapan Air pada Bata Beton Berlubang dengan Bahan Ikat Kapur dan Abu Layang. Universitas Negeri Semarang.

Nawy dan Edward, G., 1990. Beton Bertulang. PT. ERESCO, Bandung.

Post,V., Swaminathan, R., Aloy, M. and Poncet, T., 1999. Manual on Landfill for Tannery Sludge. Regional Programme for Pollution Control in The Tanning Industry in South-East Asia.

Raghava Rao, J. and Ramasani, T., 2001. DoEcology Solutions For Leather Sector : Technology Initiatives, International Conference of South and South East Asian Countries on Leather and Allied Industry. Calcuta-India.

Sahasranaman, A., 1998. Cleaner Technologies and Trade / Commercial Aspect.
Regional Workshop on Cleaner Tanning Technologist. Madras - India.

Shackel, B., 1990. Design and Contruction of Interlocking Concrete Block Pavement. Elsevier Applied Science. London England.

SNI 03 0028-1987 ICS 91.060.30, Ubin Semen Polos. Dewan Standardisasi Nasional.

SNI 03-348-1989. Mutu dan Cara uji Bata Beton Berlubang.

SNI 03-0691-1996 ICS 91.100.30. Bata Beton (Paving Block). Dewan Standardisasi Nasional.

Sri Sutiyasmi, I. Sunaryo, Hadi Mustafa dan Joko Susilo, 2004. Pemanfaatan Lumpur Limbah Industri Penyamakan Kulit untuk Kompos dan Pengaruhnya Terhadap Kandungan Krom dalam Tanaman Uji (Jagung dan Sawi). Majalah Kulit, Karet dan Plastik. Vol 20. No. 1 Juli 2004. ISSN 1829-6971.

Sudarmoko dan Hariyanto, T., 2001. Genteng Beton dengan Substitusi Tras. Forum Teknik Jilid2.

Thierry Poncet, 1998. Tannery Sludge Management. Text of Papers: The $4^{\text {th }}$ Asian International Conference of Leather Science and Technology, Beijing - China

Tjokrodimulyo dan Kardiono, 1996. Teknologi Beton. Penerbit Nafitri Yogyakarta. Hal $1-61$. 